University of Nebraska - Lincoln

DigitalCommons@University of Nebraska - Lincoln

\title{
Determination of root biomasses of three species grown in a mixture using stable isotopes of carbon and nitrogen
}

H. Wayne Polley

USDA, wayne.polley@ars.usda.gov

Hyrum B. Johnson

USDA

Herman S. Mayeux

USDA

Follow this and additional works at: https://digitalcommons.unl.edu/usdaarsfacpub

Part of the Agricultural Science Commons

Polley, H. Wayne; Johnson, Hyrum B.; and Mayeux, Herman S., "Determination of root biomasses of three species grown in a mixture using stable isotopes of carbon and nitrogen" (1992). Publications from USDAARS / UNL Faculty. 449.

https://digitalcommons.unl.edu/usdaarsfacpub/449

This Article is brought to you for free and open access by the U.S. Department of Agriculture: Agricultural Research Service, Lincoln, Nebraska at DigitalCommons@University of Nebraska - Lincoln. It has been accepted for inclusion in Publications from USDA-ARS / UNL Faculty by an authorized administrator of DigitalCommons@University of Nebraska - Lincoln. 


\title{
Determination of root biomasses of three species grown in a mixture using stable isotopes of carbon and nitrogen
}

\author{
H. WAYNE POLLEY, HYRUM B. JOHNSON and HERMAN S. MAYEUX \\ USDA, Agricultural Research Service, Grassland, Soil and Water Research Laboratory, \\ 808 E. Blackland Rd., Temple, TX 76502, USA
}

Received 27 June 1991. Revised November 1991

Key words: $\delta^{13} \mathrm{C}, \%{ }^{15} \mathrm{~N}$, Celtis laevigata, Gossypium hirsutum, Glycine max, Prosopis glandulosa, Schizachyrium scoparium, Sorghum bicolor

\begin{abstract}
A method is evaluated that employs variation in stable $\mathrm{C}$ and $\mathrm{N}$ isotopes from fractionations in $\mathrm{C}$ and $\mathrm{N}$ acquisition and growth to predict root biomasses of three plant species in mixtures. Celtis laevigata Willd. $\left(\mathrm{C}_{3}\right)$, Prosopis glandulosa Torr. $\left(\mathrm{C}_{3}\right.$, legume) and Schizachyrium scoparium (Michx.) Nash $\left(\mathrm{C}_{4}\right)$, or Gossypium hirsutum L. $\left(\mathrm{C}_{3}\right)$, Glycine max (L.) Merr. $\left(\mathrm{C}_{3}\right.$ legume), and Sorghum bicolor (L.) Moench $\left(C_{4}\right)$ were grown together in separate, three-species combinations. Surface roots $(0-10 \mathrm{~cm}$ depth) of each species from each of the two combinations were mixed in various proportions, and the relative abundances of ${ }^{15} \mathrm{~N}$ and ${ }^{14} \mathrm{~N}$ and ${ }^{13} \mathrm{C}$ and ${ }^{12} \mathrm{C}$ in prepared mixtures, surface roots of single species, and roots extracted from the $80-\mathrm{cm}$ soil profile in which each species combination was grown were analyzed by mass spectrometry. An algebraic determination which employed the $\delta{ }^{13} \mathrm{C}, \%{ }^{1.5} \mathrm{~N}$, and $\mathrm{C}$ and $\mathrm{N}$ concentrations of root subsamples of individual species accounted for more than $95 \%$ of the variance in biomass of each species in prepared mixtures with $G$. max, G. hirsutum, and S. bicolor. A similar analysis demonstrated species-specific differences in rooting patterns. Root biomasses of the $C_{t}$ monocots in each combination, $S$. scoparium and $S$. bicolor, were concentrated in the upper $20 \mathrm{~cm}$ of soil, while those of $G$. hirsutum and the woody $P$. glandulosa were largest in lower soil strata. Analyses of stable $\mathrm{C}$ and $\mathrm{N}$ isotopes can effectively be used to distinguish roots of species which differ in ratios of ${ }^{15} \mathrm{~N}$ to ${ }^{14} \mathrm{~N}$ and ${ }^{13} \mathrm{C}$ to ${ }^{12} \mathrm{C}$ and thus to study belowground competition between or rooting patterns of associated species with different $\mathrm{C}$ and $\mathrm{N}$ isotope signatures. The method evaluated can be extended to quantify aboveground and belowground biomasses of component species in mixtures with isotopes of other elements or element concentrations that differ consistently among plants of interest.
\end{abstract}

\section{Introduction}

Roots are an important, sometimes dominant, component of plant biomass. However, understanding of the structure and distribution of root systems of individual plants, particularly as related to partitioning of belowground resources and competition among plants, has been limited by the inaccessiblity of roots and inadequacies of the techniques used to distinguish roots by species. Commonly-used manual methods to separate roots by species are tedious and extremely difficult in mixtures with multiple species. Recent innovations which employ near infrared reflectance spectroscopy (Rumbaugh et al., 1988) or species differences in root fluorescence (Caldwell et al., 1985, 1987) to distinguish roots by species have not been widely tested. Studies which correlate patterns of soil water utilization with leaf water potential or physiological activity (Davis and Mooney, 1986) or which assess plant recovery of radioactive isotope (Cal- 
dwell et al., 1985, 1987), stable isotope (McKane et al., 1990), or rare chemical tracers (Fitter, 1986; Veresoglou and Fitter, 1984) applied to soil provide evidence of root activity at a particular location, but only indirect information on root biomass.

Marked differences in ratios of the stable carbon (C) isotopes ${ }^{13} \mathrm{C}$ and ${ }^{12} \mathrm{C}$, expressed as $\delta{ }^{13} \mathrm{C}$, distinguish $\mathrm{C}_{3}$ and $\mathrm{C}_{4}$ species. Mean $\delta^{13} \mathrm{C}$ values range from near $-26 \%$ for $\mathrm{C}_{3}$ plants to about $-12 \%$ for $C_{4}$ species (Smith and Epstein, 1971). This difference in $\mathrm{C}$ isotope signature has been used to determine the relative proportions of $\mathrm{C}_{3}$ and $\mathrm{C}_{4}$ plants in diets of insect and mammalian herbivores (Boutton et al., 1983; Pinder and Kroh, 1987; Tieszen et al., 1979; Tieszen and Imbamba, 1980), soil organic matter (Dzurec et al., 1985; Tieszen and Boutton, 1989), and aboveground (Ludlow et al., 1976) and root biomasses in species mixtures (Svejcar and Boutton, 1985; Svejcar et al., 1988).

Differences between $\mathrm{N}_{2}$-fixing and non- $\mathrm{N}_{2}$ fixing plants in the ratios of stable nitrogen $(\mathrm{N})$ isotopes ${ }^{15} \mathrm{~N}$ to ${ }^{14} \mathrm{~N}$ also have been widely documented (Shearer et al., 1983; Shearer and Kohl, 1986; Virginia and Delwiche, 1982). These differences, which result from generally small variation in the natural abundance of ${ }^{15} \mathrm{~N}$ between atmospheric and soil pools of $\mathrm{N}$, have not been exploited to distinguish root biomasses of $\mathrm{N}_{2}$-fixing and non- $\mathrm{N}_{2}$-fixing plants. The utility of multiple stable isotopes to separate roots of single species or functional groups of plants grown in mixtures also has not been investigated. We describe a method to determine root biomasses of potentially $\mathrm{N}_{2}$-fixing $\mathrm{C}_{3}$, non- $\mathrm{N}_{2}$-fixing $\mathrm{C}_{3}$, and $\mathrm{C}_{4}$ plants in species mixtures with differences in the ratios of stable $\mathrm{C}$ and $\mathrm{N}$ isotopes of plant material that extends previous work distinguishing $\mathrm{C}_{3}$ and $\mathrm{C}_{4}$ species with stable $\mathrm{C}$ isotopes (Ludlow et al., 1976; Svejcar and Boutton, 1985).

\section{Methods}

\section{Species mixtures}

Two seedlings each of Celtis laevigata Willd. (Texas sugarberry; $\mathrm{C}_{3}$ ) and Prosopis glandulosa
Torr. (honey mesquite; $\mathrm{C}_{3}$, legume) and Schizachyrium scoparium (Michx.) Nash (little bluestem; $\mathrm{C}_{4}$ ) grown from seed were established 28 March, 1989 in a glasshouse in two rows of three plants in each of three containers $63.5 \mathrm{~cm}$ on a side with a soil depth of $80 \mathrm{~cm}$. Approximately $600 \mathrm{~g}$ of ground plant material labeled with ${ }^{15} \mathrm{~N}\left(\%{ }^{15} \mathrm{~N}=7.54\right)$ was mixed systematically and thoroughly with soil added to each container to provide a uniform distribution of ${ }^{15} \mathrm{~N}$ label in soil profiles prior to planting. The soil is classified as Alfisol, Udic Paleustalfs, fine, mixed thermic of the series Pedernales fine sandy loam (Huckabee et al., 1977). Plants of each species were grown adjacent to plants of each of the other two species. Glycine max (L.) Merr. (soybean; $\mathrm{C}_{3}$, legume), Gossypium hirsutum L. (cotton; $\mathrm{C}_{3}$ ), and Sorghum bicolor (L.) Moench (sorghum; $\mathrm{C}_{4}$ ) were grown from seed planted 9 May, 1989 in a similar arrangement in three additional containers to which one $\mathrm{g}$ of $G$. max rhizobial inoculum was added before planting. Soil water content was monitored by neutron attenuation with a Troxler Model 3218 surface moisture gauge ${ }^{1}$ (Troxler Electronics Laboratories, Research Triangle Park, NC, USA) and was restored weekly to field capacity.

Surface roots $(0-10 \mathrm{~cm}$ depth $)$ attached to aboveground tissues of each plant of $G$. $\max , G$. hirsutum, and S. bicolor were harvested $20 \mathrm{Sep}$ tember, 1989 and those of $C$. laevigata, $P$. glandulosa, and $S$. scoparium were collected 26 October, 1989. Three soil cores, each $4.5 \mathrm{~cm}$ in diameter, were taken between and adjacent to each of the two rows of plants for a total of nine cores per container. Cores which sampled 3.5\% of the soil surface area were divided into four $20-\mathrm{cm}$ depth increments. Soil was washed from roots of $G$. max, G. hirsutum, and S. bicolor, organic debris was separated by hand, and nodules were removed from roots of $G$. $\max$. Roots of $C$. laevigata, $P$. glandulosa, and $S$. scoparium were separated by hand from ovendried soils. All roots were again washed, shaken for $1 \mathrm{hr}$ in $0.1 \mathrm{M} \mathrm{HCl}$ to remove adhering soil carbonates, oven-dried at $60^{\circ} \mathrm{C}$, and weighed. Roots separated from each of the nine soil cores

\footnotetext{
'Mention of a propriety product does not constitute an endorsement or recommendation for its use by USDA.
} 
per container were composited by depth. Surface roots of each plant and those collected from species mixtures from each soil stratum per container were ground in a ball mill. Samples of surface roots from one container each of the two, three-species combinations were mixed to create a range of 0 to $100 \% \mathrm{C}_{4}$ biomass or 0 to $100 \%$ legume biomass. The remaining biomass in mixture contained equal proportions of the two other species.

\section{Stable isotope analyses}

Sample of surface roots from each plant, roots separated from soil cores from species mixtures, and prepared root mixtures were analyzed for total $\mathrm{C}$ and $\mathrm{N}$ concentrations following Dumas combustion (Morris et al., 1968). The relative abundances of ${ }^{15} \mathrm{~N}$ and ${ }^{14} \mathrm{~N}$ in $\mathrm{N}_{2}$ gas and of ${ }^{13} \mathrm{C}$ and ${ }^{12} \mathrm{C}$ in $\mathrm{CO}_{2}$ from combustion were analyzed by mass spectrometry by B. B. McInteer of Isotope Services, Inc. Results were expressed as $\%{ }^{15} \mathrm{~N}$ relative to atmospheric $\mathrm{N}_{2}$ and as $\delta^{13} \mathrm{C}$, $\% e{ }^{1.3} \mathrm{C}$ relative to a PeeDee belemnite reference standard (PDB) where

$$
\delta{ }^{13} \mathrm{C}=\left[\frac{\mathrm{R}_{\text {sample }}}{\mathrm{R}_{\text {standard }}}-1\right] \times 10^{3},
$$

and $\mathrm{R}_{\text {sample }}$ and $\mathrm{R}_{\text {standard }}$ are the molar abundance ratio, ${ }^{13} \mathrm{C} /{ }^{12} \mathrm{C}$, of plant material and the $\mathrm{PDB}$ standard $(\mathrm{R}=0.01124)$, respectively. Units of $\%{ }^{15} \mathrm{~N}$ conventionally are employed when ${ }^{15} \mathrm{~N}$ is enriched. Differences in natural ${ }^{15} \mathrm{~N}$ abundance between plants and the atmosphertic $\mathrm{N}_{2}$ standard are smaller than those measured with ${ }^{15} \mathrm{~N}$ enrichment and, like ${ }^{13} \mathrm{C}$, are expressed conventionally as $\delta{ }^{15} \mathrm{~N}$, the per mil ${ }^{15} \mathrm{~N}$ excess over the standard (Shearer and Kohl, 1986). Results are means of two determinations per sample. The mean (standard deviation) of the difference between replicate combustions of the same sample was $0.0046(0.0048) \%{ }^{15} \mathrm{~N}$ and $0.14(0.02) \%$ $\delta^{1.3} \mathrm{C}, n=78$.

\section{Theory - use of stable isotopes to distinguish species in mixtures}

The stable isotope signature of a species mixture reflects the isotope signatures of component species and their proportions in the mixture. Stable isotopes thus can be used to determine biomasses of species in mixtures when each has a distinctive isotope signature. The ratios of stable $\mathrm{C}$ or $\mathrm{N}$ isotopes of all but a single species in a mixture must be similar to isotopically distinguish biomass of one of three species. The consistent dichotomy in $\delta^{13} \mathrm{C}$ between $\mathrm{C}_{3}$ and $\mathrm{C}_{4}$ species satisfies this criterion when mixtures include $C_{3}$ and $C_{4}$ components, though ratios of stable isotopes of other elements may prove equally effective to separate single species in some situations. Biomasses of the two remaining species can be distinguished if they differ in the ratio of stable isotopes of a second element.

Svejcar and Boutton (1985) found a strong linear relationship between the proportion of $\mathrm{C}_{4}$ biomass in $\mathrm{C}_{3} / \mathrm{C}_{4}$ mixtures and the $\delta^{13} \mathrm{C}$ of mixtures. Ludlow et al. (1976) estimated the percentage of $\mathrm{C}_{3}$ or $\mathrm{C}_{4}(\mathrm{~A}, \mathrm{~B})$ species in root biomass of mixtures $(\mathrm{A}+\mathrm{B})$ with $\delta^{1,3} \mathrm{C}$ values, where

$$
\% \text { component } \mathrm{B}=\left[\frac{\delta^{1.3} \mathrm{C}_{\mathrm{A}+\mathrm{B}}-\delta^{13} \mathrm{C}_{\mathrm{A}}}{\delta^{13} \mathrm{C}_{\mathrm{B}}-\delta^{1.3} \mathrm{C}_{\mathrm{A}}}\right] \times 100
$$

The contribution of single species with different ratios of stable $\mathrm{N}$ isotopes to the $\%^{15} \mathrm{~N}$ (or $\delta^{15} \mathrm{~N}$ ) of species mixtures can be estimated similarly. However, to determine species biomasses from these analyses it must be assumed that the contribution of each to the $\delta^{13} \mathrm{C}$ or $\%{ }^{15} \mathrm{~N}$ of mixtures is directly proportional to biomass, that is that the $\mathrm{C}$ or $\mathrm{N}$ contents of biomass of component species are similar. This assumption is eliminated if the contributions of species to the stable $\mathrm{C}$ and $\mathrm{N}$ isotope signatures of mixtures are weighted by their $\mathrm{C}$ and $\mathrm{N}$ concentrations.

The mass of ${ }^{13} \mathrm{C}$ or ${ }^{15} \mathrm{~N}$ in roots of a species mixture is the sum of the products of the ratios of ${ }^{13} \mathrm{C}$ to total $\mathrm{C}\left({ }^{12} \mathrm{C}+{ }^{13} \mathrm{C}\right)$ or ${ }^{15} \mathrm{~N}$ to total $\mathrm{N}$ $\left({ }^{14} \mathrm{~N}+{ }^{15} \mathrm{~N}\right)$, derived from $\delta^{1.3} \mathrm{C}$ or $\%_{0}^{1.5} \mathrm{~N}$ values, and root $\mathrm{C}$ or $\mathrm{N}$ (biomass $* \%$ element composition) of component species. The $\mathrm{C}$ mass of the $\mathrm{C}_{+}$species in experimental mixtures was distinguished from that of the two $\mathrm{C}_{3}$ species with its distinctive ratio of ${ }^{1.3} \mathrm{C}$ to total $\mathrm{C}$. The $\mathrm{C}_{4}$ biomass in mixtures was determined as

$$
\mathrm{ax}+\mathrm{by}=\mathrm{cz} \text {, }
$$


where $\mathrm{a}, \mathrm{b}$, and $\mathrm{c}$ are the products of mean ${ }^{13} \mathrm{C} /$ total $\mathrm{C}$ and $(\%$ root $\mathrm{C}) / 100$ of the $\mathrm{C}_{4}$ species, two $\mathrm{C}_{3}$ species, and root mixture, respectively, and $x, y$, and $z$ are root biomasses of the $\mathrm{C}_{4}$ species, two $\mathrm{C}_{3}$ species, and root mixture, respectively. Substituting known biomass of the root mixture, $z$, yields an equation that can be solved for $\mathrm{x}$, the root biomass of the $\mathrm{C}_{4}$ species in mixture:

$$
\begin{aligned}
& a x+b(z-x)=c z \\
& x=(c-b) z /(a-b)
\end{aligned}
$$

The contribution of one of the two $\mathrm{C}_{3}$ species to mass of ${ }^{15} \mathrm{~N}$ remaining after subtracting that of $\mathrm{C}_{4}$ plants was determined with the $\%{ }^{15} \mathrm{~N}$ value and $\mathrm{N}$ concentration of the species. Root biomasses of the $\mathrm{C}_{4}$ species and of the root mixture were substituted into a algebraic expression similar to Eq. 4, with (\% root $\mathrm{N}$ )/100 of the root mixture and individual species, to solve for biomass of either the legume or non- $\mathrm{N}_{2}$-fixing $\mathrm{C}_{3}$ species. Biomass of the third species was determined by difference from biomass of the composite sample. Biomasses of $\mathrm{C}_{3}$ 's may be calculated by Eq. 4 without including ${ }^{15} \mathrm{~N}$ abundances, when $\mathrm{N}$ concentrations of the legume and remaining $\mathrm{C}_{3}$ species differ consistently. Little error results at natural isotope abundances when the ratios of ${ }^{13} \mathrm{C}$ to total $\mathrm{C}$ and ${ }^{15} \mathrm{~N}$ to total $\mathrm{N}$ in the above solution are replaced by $\delta{ }^{13} \mathrm{C}$ and $\%^{15} \mathrm{~N}$ (or $\left.\delta^{15} \mathrm{~N}\right)$.

\section{Results}

\section{Individual species}

The $\delta{ }^{13} \mathrm{C}$ of $S$. biocolor $(\bar{x}=-11.35 \%$ ) and $S$. scoparium $(\bar{x}=-12.26 \%$ ) roots were within the range of values commonly reported for tissue of $\mathrm{C}_{4}$ species, values consistently less negative (less discrimination against ${ }^{13} \mathrm{C}$ ) than those of the two $\mathrm{C}_{3}$ species in each three-species combination (Fig. 1). There was a greater difference in $\delta{ }^{13} \mathrm{C}$ of $C_{3}$ species $P$. glandulosa $(\bar{x}=-27.76 \%)$ and C. laevigata $(\bar{x}=-25.96 \%$ o $)$ in mixture than between the $\mathrm{C}_{3}$ species $G$. hirsutum $(\bar{x}=$ $-26.07 \%$ ) and $G . \max (\bar{x}=-26.28 \% 0)$. Intras-

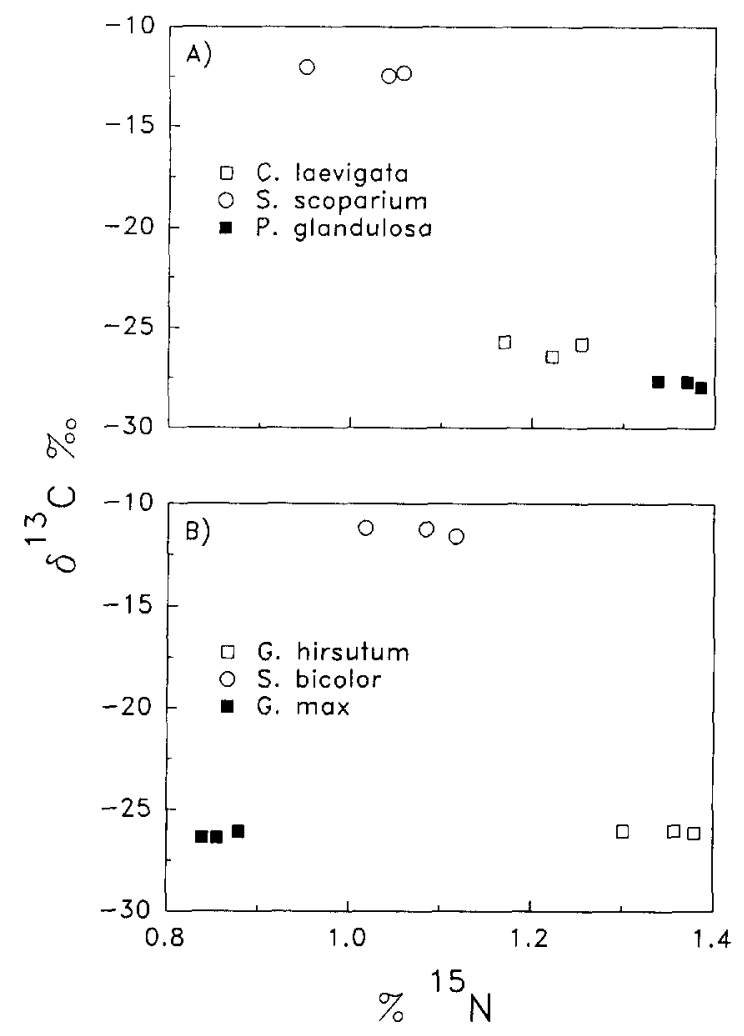

Fig. 1. The $\delta^{13} \mathrm{C}$ and $\%{ }^{15} \mathrm{~N}$ of roots of (A) C. laevigata, $P$. glandulosa, and $S$. scoparium and (B) G. max, G. hirsutum, and $S$. bicolor grown in ${ }^{15} \mathrm{~N}$-enriched soil. Points are means for surface roots $(0-10 \mathrm{~cm}$ depth) of two plants of each species from each of three soil containers with each species combination.

pecific variation in $\delta{ }^{13} \mathrm{C}$ within each container generally was minimal (range 0.01 to $1.19 \%$, $\bar{x}=0.33 \%$ ). Root $\mathrm{C}$ concentration was lowest in S. bicolor $(\bar{x}=41.23 \%)$, but differed little among the other five species (range 45.37 to $47.04 \%$ ). In contrast, the $\%{ }^{15} \mathrm{~N}$ of roots varied consistently among the three species in each combination. The $\%{ }^{15} \mathrm{~N}$ of $G$. $\max$ was nearer the atmospheric value of 0.3663 atom $\%{ }^{15} \mathrm{~N}$ than that of $G$. hirsutum and $S$. bicolor in the same mixture, indicating that $G$. $\max$ fixed atmospheric $\mathrm{N}_{2}$. Roots of $G$. hirsutum and $S$. bicolor differed in ${ }^{15} \mathrm{~N}$ abundance, possibly because of temporal variation in release of ${ }^{15} \mathrm{~N}$ from added organic matter and plant $\mathrm{N}$ uptake. $P$. glandulosa, known to nodulate in the soil used (personal observ.), apparently did not fix $\mathrm{N}_{2}$, but had a distinctively higher $\%{ }^{15} \mathrm{~N}$ value than associated species. The $\mathrm{N}$ concentration of surface roots of 
the two legumes, $P$. glandulosa $(\bar{x}=1.38 \%)$ and G. $\max (\bar{x}=0.67 \%)$, was about twice that of other species in each mixture.

\section{Prepared mixtures}

There was a highly significant relationship between the actual and predicted biomasses of $\mathrm{C}_{4}$ and legume species in prepared mixtures with $C$. laevigata, P. glandulosa, and S. scoparium (Fig. 2 ) and G. max, G. hirsutum, and S. bicolor (Fig. $3)$. The algebraic determination which employed the $\delta{ }^{1.3} \mathrm{C}, \%{ }^{15} \mathrm{~N}$, and $\mathrm{C}$ and $\mathrm{N}$ concentrations of root subsamples of individual species accounted for more than $98 \%$ of the variance in biomass of both $\mathrm{C}_{4}$ and legume plants in prepared mixtures

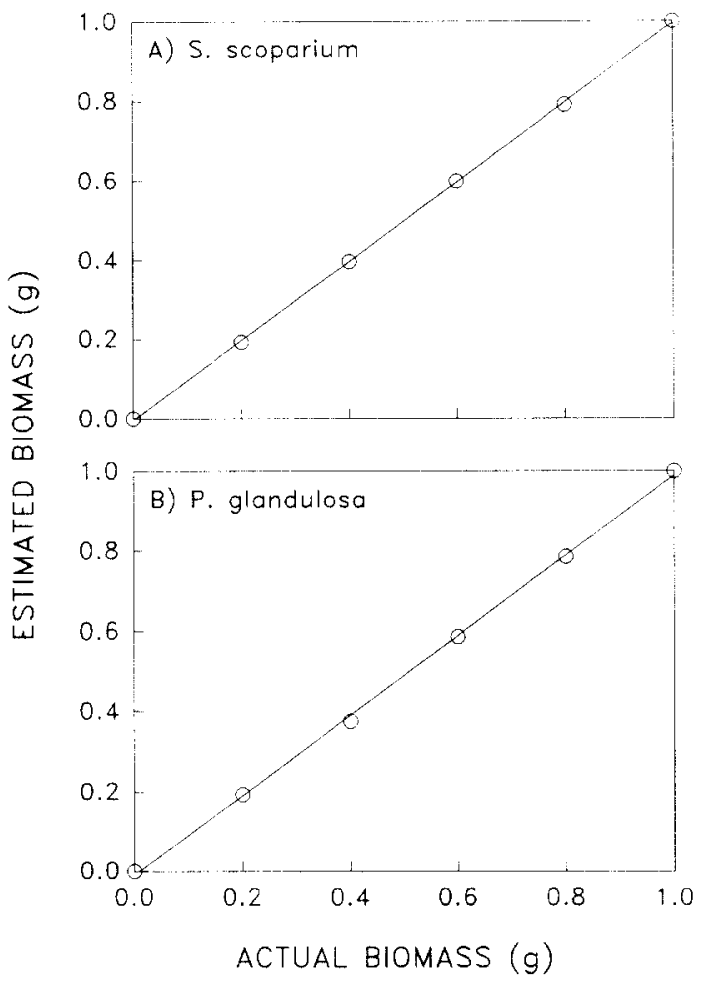

Fig. 2. Relationship between root biomass of (A) the $C_{4}$ grass $S$. scoparium and $(\mathbf{B})$ the $\mathrm{C}_{3}$ woody legume $P$. glandulosa in prepared mixtures with roots of $S$. scoparium, $P$. glandulosa, and $C$. laevigata and root biomass of species estimated algebraically with the $\delta^{13} \mathrm{C}, \%{ }^{15} \mathrm{~N}$, and $\mathrm{C}$ and $\mathrm{N}$ concentrations of mixtures and subsamples of roots of individual species. Solid lines are linear regressions for $S$. scoparium $\left(\mathrm{Y}=0.0034+0.998(\mathrm{X}), r^{2}=0.999, p<0.0001\right)$ and $P$. glandulosa $\left(\mathrm{Y}=-0.0091+0.998(\mathrm{X}), r^{2}=0.999 . p<\right.$ $0.0001), n=6$.

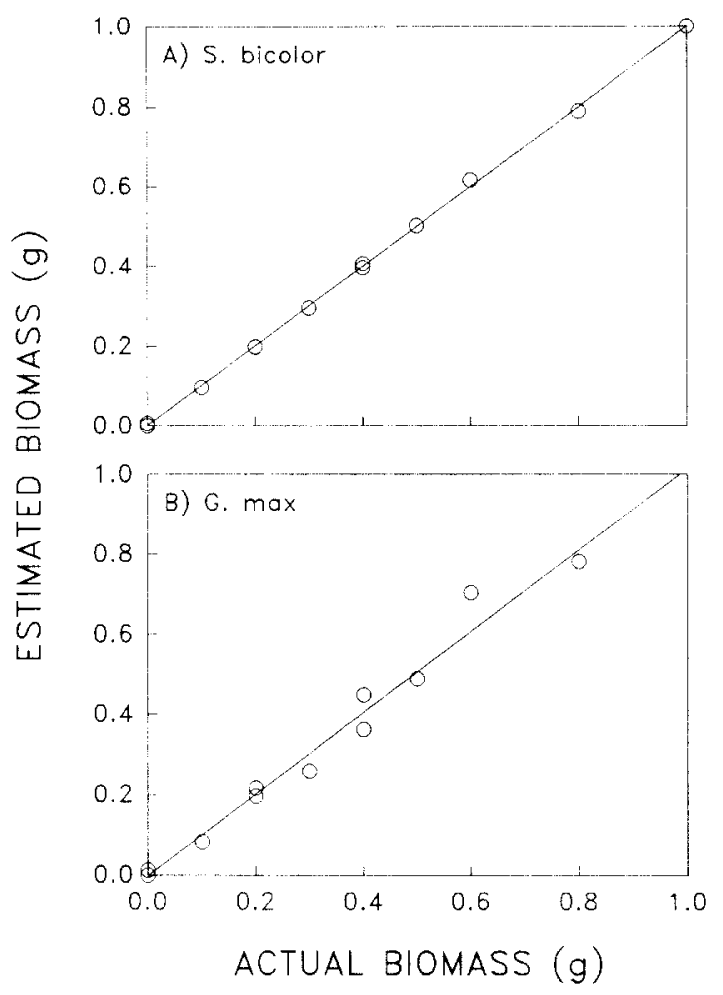

Fig. 3. Relationship between root biomass of (A) the $\mathrm{C}_{4} S$. bicolor and (B) the $\mathrm{C}_{3}$ legume $G$. max in prepared mixtures with roots of S. bicolor, G. max, and $G$. hirsutum and root biomass of species estimated algebraically with the $\delta{ }^{1.3} \mathrm{C}$, $\%{ }^{15} \mathrm{~N}$, and $\mathrm{C}$ and $\mathrm{N}$ concentrations of mixtures and subsamples of roots of individual species. Solid lines are linear regressions for $S$. bicolor $\left(Y=0.0014+0.999(X), r^{2}=0.999\right.$. $p<0.0001)$ and $G . \max \left(\mathrm{Y}=-0.0013+1.02(\mathrm{X}), r^{2}=0.985\right.$, $p<0.0001), n=12$.

with three species. The estimate of root biomass of $G$. hirsutum in mixtures with $G$. max and $S$. bicolor by difference accounted for $95 \%$ of the variance in biomass of this $\mathrm{C}_{3}$ species (predicted biomass $=-0.00638+1.00447$ (actual biomass), $p<0.0001, n=12$ ).

\section{Species mixtures}

The algebraic approach was modified to determine the contribution of individual species to root biomass in soil because roots separated from soils with each species combination had lower $\mathrm{C}$ concentrations and sometimes higher $\mathrm{N}$ concentrations than did surface roots of component species. Mass of $\mathrm{C}$ in $\mathrm{C}_{4}$ roots was solved with Eq. 4. Biomass of the $C_{4}$ then was de- 
termined with the ratio of $\mathrm{C}$ concentration of $\mathrm{C}_{4}$ surface roots to the mean $\mathrm{C}$ concentration of surface roots of $C_{3}$ species. Nitrogen mass of one of the two $\mathrm{C}_{3}$ species then was estimated from an equation similar to (4) using the mean $\%{ }^{15} \mathrm{~N}$ of the $\mathrm{C}_{4}$ and remaining $\mathrm{C}_{3}$ species. Root biomass of the single $\mathrm{C}_{3}$ species was derived from calculated $\mathrm{N}$ mass with the ratio of root $\mathrm{N}$ concentration of the species to the $\mathrm{N}$ concentration measured on surface roots of the remaining species.

The modified algebraic solution yielded negative values of a mean $13 \%$ and $19 \%$ of total biomass for $P$. glandulosa and $G$. hirsutum, respectively, in the $0-20 \mathrm{~cm}$ layers of some core profiles. Biomasses of surface roots extracted from directly beneath individual plants were not added to calculated biomasses in soil cores. Negative values were set to zero, and the ratios of calculated biomasses of remaining species were used to partition total root biomass among species.

Total root biomass did not differ significantly between mixtures with G. $\max , G$. hirsutum, and $S$. bicolor and those with $C$. laevigata, $P$. glandulosa, and $S$. scoparium $(\bar{x} \pm \mathrm{SE}=166.1 \pm 12.6$ and $142.5 \pm 12.2 \mathrm{~g}$, respectively), but the distribution of roots with depth differed markedly between the two three-species mixtures (Fig. 4). Root biomass was more evenly distributed in mixtures with $C$. laevigata, $P$. glandulosa, and $S$. scoparium with a non-significant $(p>0.05)$ maximum in the lower $20-\mathrm{cm}$ stratum. Conversely, root biomass in mixtures with herbaceous species $G$. max, G. hirsutum, and $S$. bicolor clearly was concentrated in the upper $20 \mathrm{~cm}$ of the soil profile.

The more uniform rooting pattern in mixtures of C. laevigata, P. glandulosa, and S. scoparium belied the species differences in root distribution indicated by changes in mean isotope values of mixed roots with depth (Table 1). The calculated relative contribution of the $\mathrm{C}_{4}$ grass, $S$. scoparium, to total root biomass declined in lower soil strata (Fig. 4a) as the $\delta{ }^{13} \mathrm{C}$ became more negative and the $\%{ }^{15} \mathrm{~N}$ of roots from cores increased (Table 1) from values indicative of $S$. scoparium in these mixtures (Fig. 1a). Estimated root biomass of the $\mathrm{C}_{3} C$. laevigata was largest in the upper $20 \mathrm{~cm}$ stratum, while that of the $\mathrm{C}_{3}$

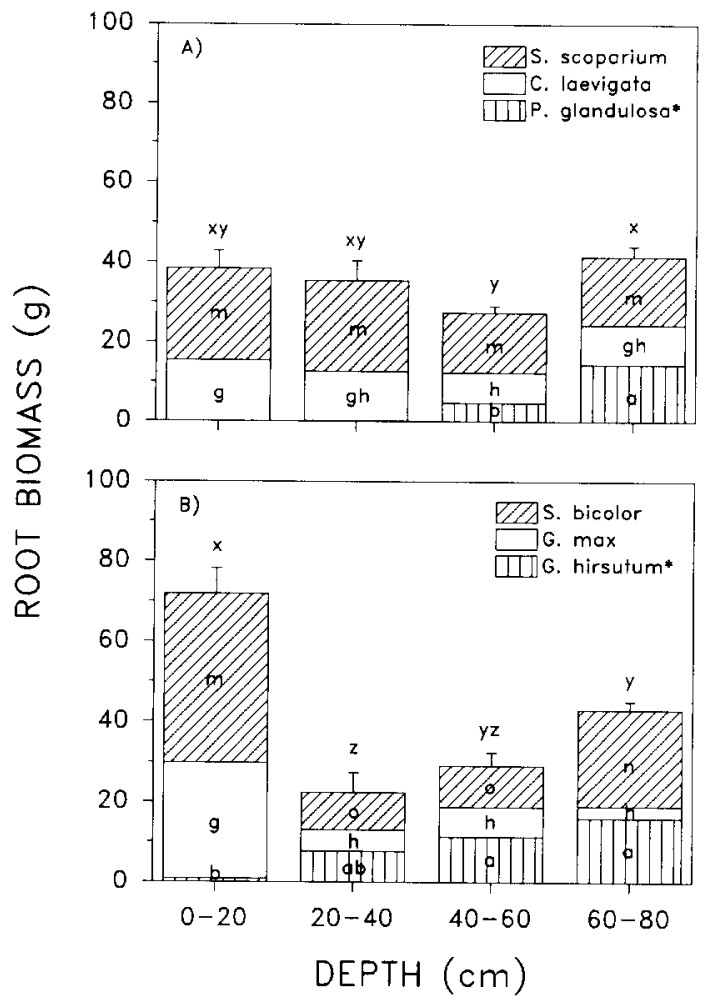

Fig. 4. Calculated root biomass with depth of three species grown in mixtures in ${ }^{15} \mathrm{~N}$-enriched soil, (A) $C$. laevigata, $P$. glandulosa, and S. scoparium and (B) G. max, G. hirsutum, and $S$. bicolor $(n=3)$. Root biomass of each species was estimated algebraically with the $\delta^{13} \mathrm{C}, \%{ }^{15} \mathrm{~N}$, and $\mathrm{C}$ and $\mathrm{N}$ concentrations of subsamples of surface roots $(0-10 \mathrm{~cm}$ depth) of individual species and roots recovered from nine soil cores per mixture. Total biomass $(x, y$ or $z)$ or that of individual species are not significantly different $(p<0.05)$ across depth increments by Duncan's multiple range test when labelled with the same lower-case letter. Error bars indicate 1 standard error of total root biomass. ${ }^{*}$ Calculations yielded negative values of root biomass for $P$. glandulosa and $G$. hirsutum in the $0-20 \mathrm{~cm}$ layers of some profiles. The estimated negative values of biomass for these species in soil cores likely occurred because the $\mathrm{C}$ and $\mathrm{N}$ concentrations of surface roots, including tap roots, of individual species used in calculations differed from those of roots extracted from cores. Negative values were set to zero.

legume $P$. glandulosa was largest in the lower stratum (Fig. 4a).

Root biomasses of both the $\mathrm{C}_{4} S$. bicolor and $\mathrm{C}_{3}$ legume $G$. max were concentrated in the upper $20 \mathrm{~cm}$ of soil (Fig. 4b). Contribution of these species to total root biomass generally declined and that of the $\mathrm{C}_{3} G$. hirsutum increased with depth, a trend reflected in the more 
Table 1. The $\delta^{1.3} \mathrm{C}$ and $\%{ }^{15} \mathrm{~N}$ of roots by depth in 80-cm soil profiles in which Celtis laevigata, Prosopis glandulosa, and Schizachyrium scoparium, or Glycine max, Gossypium hirsutum, and Sorghum bicolor were grown. Values are means of three determinations, each with roots composited from nine soil cores, weighted by $\mathrm{C}\left(\delta^{13} \mathrm{C}\right)$ and $\mathrm{N}\left(\%^{15} \mathrm{~N}\right)$ masses in replicate species mixtures

\begin{tabular}{llllll}
\hline & \multicolumn{2}{l}{ Mixture } & \\
\cline { 2 - 3 } & $\begin{array}{l}\text { Celtis/Prosopis } \\
\text { Schizachyrium }\end{array}$ & & \multicolumn{2}{l}{$\begin{array}{l}\text { Glycine/Gossypitum } \\
\text { /Sorghum }\end{array}$} \\
\cline { 2 - 3 } $\begin{array}{l}\text { Depth } \\
(\mathrm{cm})\end{array}$ & $\delta^{1 \cdot \mathrm{C}}$ & $\%^{15} \mathrm{~N}$ & & $\delta^{1.3} \mathrm{C}$ & $\%^{15} \mathrm{~N}$ \\
\hline $0-20$ & -16.74 & 1.03 & & -14.10 & 0.94 \\
$20-40$ & -17.11 & 1.11 & & -18.74 & 1.08 \\
$40-60$ & -18.65 & 1.19 & & -19.47 & 1.09 \\
$60-80$ & -20.74 & 1.25 & & -16.02 & 1.10 \\
\hline
\end{tabular}

negative, $\mathrm{C}_{3}$-like $\delta{ }^{13} \mathrm{C}$ values and higher $\%{ }^{15} \mathrm{~N}$ values of roots from lower soil strata (Table 1).

The $C_{4}$ species in each mixture, $S$. scoparium or $S$. bicolor, dominated aboveground as well as belowground biomass (Fig. 4). S. scoparium and $S$. bicolor contributed a mean $51 \%$ and $67 \%$ $(n=3)$, respectively, of total aboveground biomass in mixtures. Conversely, aboveground biomasses of $P$. glandulosa and $C$. laevigata constituted a mean of only $10 \%$ and $11 \%(n=3)$, respectively, of the total in mixtures.

\section{Discussion}

Use of stable isotopes to determine root biomasses in mixtures

The results indicate that analyses of stable $\mathrm{C}$ and $\mathrm{N}$ isotopes can effectively be used to distinguish roots of species with different $\mathrm{C}$ and $\mathrm{N}$ isotope signatures. Results thus extend previous work that demonstrated the utility of stable $\mathrm{C}$ isotopes to discern biomass of $\mathrm{C}_{3}$ and $\mathrm{C}_{4}$ species (Ludlow et al., 1976; Svejcar and Boutton, 1985).

Ludlow et al. (1976) used only $\delta^{13} \mathrm{C}$ values to calculate contribution of $\mathrm{C}_{3}$ and $\mathrm{C}_{4}$ components to biomass of two-species mixtures (Eq. 1) with the assumption that $\mathrm{C}$ was the same proportion of biomass in all samples and the ratio of ${ }^{1.3} \mathrm{C}$ to ${ }^{12} \mathrm{C}$ approximated the ratio of ${ }^{13} \mathrm{C}$ to total $\mathrm{C}$. The latter assumption introduces a minor error in calculation of biomasses of components in a $\mathrm{C}_{3} / \mathrm{C}_{4}$ mixture since ${ }^{12} \mathrm{C}$ is $98.9 \%$ of total $\mathrm{C}$ at natural abundances of ${ }^{13} \mathrm{C}$. Similarly, this solution would introduce little error in discerning biomasses of species with different $\%{ }^{15} \mathrm{~N}$ (or $\delta^{15} \mathrm{~N}$ ) values near natural abundances of stable $\mathrm{N}$ isotopes. However, the biomasses of species in mixtures will be estimated with error by the method of Ludlow et al. if $\mathrm{C}$ or $\mathrm{N}$ concentrations of species differ. The species in a mixture with the highest $\mathrm{C}$ or $\mathrm{N}$ concentration contributes relatively more to the total $\mathrm{C}$ or $\mathrm{N}$ mass of the mixture, and thus to its isotope signature, than to total biomass. The contribution of that species to mixture biomass will be overestimated by isotope analysis when $\mathrm{C}$ or $\mathrm{N}$ concentrations of component biomasses are assumed to be comparable. For example, biomass of $G$. max in prepared mixtures with $G$. hirsutum and $S$. bicolor would have been overestimated had not the higher root $\mathrm{N}$ concentration of $G$. $\max$ been included in the calculation $(\vec{x}=0.68 \%$ and $0.31 \%$ root $\mathrm{N}$ for $G$. max and remaining species, respectively). The ratio of estimated to actual biomasses of $G$. max in mixtures $(\bar{x} \pm \mathrm{SE})$ was $0.991 \pm 0.036$ and $1.362 \pm 0.073(n=10)$ when calculated with and without measured differences in $\mathrm{N}$ concentrations of roots of individual species.

The approach used by Svejcar and Boutton (1985) and Svejcar et al. (1988) to estimate $C_{3}$ and $\mathrm{C}_{4}$ root biomasses from regressions of $\% \mathrm{C}_{4}$ biomass on the $\delta^{13} \mathrm{C}$ of prepared $\mathrm{C}_{3} / \mathrm{C}_{4}$ mixtures accommodates potential differences in $\mathrm{C}$ concentration between species. The $\mathrm{C}_{4}$ contribution to the $\delta^{1.3} \mathrm{C}$ of a mixture is a function both of the stable $\mathrm{C}$ isotope signatures and $\mathrm{C}$ concentrations of biomass of component species. The approach may require, however, a regression of $\% \mathrm{C}_{3}$ or $\% \mathrm{C}_{4}$ biomass on the $\delta^{13} \mathrm{C}$ of $\mathrm{C}_{3} / \mathrm{C}_{4}$ mixtures for samples with each combination of $\mathrm{C}_{3} / \mathrm{C}_{4}$ species of interest. This necessity is eliminated if biomasses of species in mixtures are determined algebraically as described above with the $\delta^{13} \mathrm{C}$ values and $\mathrm{C}$ concentrations of biomasses of mixed samples and component species.

\section{Assumptions and precautions}

The negative values of biomass estimated for tap-rooted $G$. hirsutum and $P$. glandulosa in the 0-20 cm soil layer of cores from species mixtures 
(Fig. 4) likely reflected the scarcity of roots of these species, inadequacy of sampling the highly patterned root distribution of the surface layer, and errors introduced by the additional assumptions made in calculations because $\mathrm{C}$ and particularly $\mathbf{N}$ concentrations of roots from cores differed from concentrations of surface, including tap, roots of individual species. There was a mean difference of about $11 \%$ between actual root biomasses of the two $\mathrm{C}_{3}$ species in prepared mixtures of $G$. hirsutum, G. max, and S. bicolor and biomasses calculated algebraically with the assumptions required to estimate species biomasses in soil profiles $(\bar{x}=11.4 \%$ and $10.6 \%$ for $G$. max and $G$. hirsutum, respectively). Results emphasize that care should be taken to insure that root sampling is adequate and that the stable $\mathrm{C}$ and $\mathrm{N}$ isotope values and $\mathrm{C}$ and $\mathrm{N}$ concentrations used in calculations for individual species are indicative of those of roots of each species in mixed samples.

It was assumed in calculations that stable $\mathrm{C}$ and $\mathrm{N}$ isotopes were uniformly distributed in the $\mathrm{C}$ and $\mathrm{N}$ masses of root systems and that the $\mathrm{C}$ and $\mathrm{N}$ concentrations of root subsamples were representative for the bulk of the root systems of component species. The $\delta{ }^{13} \mathrm{C}$ values of medium $(1.0-1.2 \mathrm{~mm})$ and small diameter $(0.35-$ $0.61 \mathrm{~mm}$ ) woody roots of $P$. glandulosa grown in ${ }^{15} \mathrm{~N}$-enriched soil in an independent experiment were a mean $0.6 \%$ more negative and positive, respectively, than large diameter (13.4 to 18.9 $\mathrm{mm})$ roots of the same plant $(n=3)$, but differences were variable. The $\%{ }^{15} \mathrm{~N}$ values of medium and small diameter roots of $P$. glandulosa were $0.019 \%$ and $0.010 \%$ more positive than large diameter roots with a mean $\%{ }^{15} \mathrm{~N}$ of $0.965 \%$.

The assumptions of uniform $\mathrm{C}$ and, particularly, $\mathrm{N}$ concentrations within single root systems may be especially tenuous when some roots are woody. The $\mathrm{N}$ concentration of tree roots usually decreases as root diameter increases (McClaugherty et al., 1982; Meier et al., 1985), and $\mathrm{C}$ and $\mathrm{N}$ concentrations may differ with age or development among tree roots of the same size (Goldfarb et al., 1990). We found no change in $\mathrm{C}$ concentration with root size within single woody root systems of $P$. glandulosa from another experiment, but $\mathrm{N}$ concentrations were
$81 \%$ higher in both medium- and small-diameter roots than large roots $(n=3)$. The mean $\mathrm{N}$ concentration of the entire root system of $G$. max grown in ${ }^{15} \mathrm{~N}$-amended soil in the same greenhouse with experimental plants was twice that measured on surface roots of the species in mixtures. The negative value estimated for $G$. hirsutum biomass in mixtures with G. $\max$ (Fig. 4b) was eliminated when calculations included the higher $\mathrm{N}$ concentration measured on the entire root system of $G$. max.

Temporal changes in element concentrations of tree roots generally are minimal (McClaugherty et al., 1982; Meier et al., 1985), but significant seasonal changes in $\mathrm{C}$ and $\mathrm{N}$ concentrations of grass roots have been reported (Dormaar et al., 1981). Tieszen and Boutton (1989) found seasonal variation of 1 to $2 \%$ in $\delta^{13} \mathrm{C}$ of leaves of five species of $\mathrm{C}_{4}$ grasses, and Virginia et al. (1989) described temporal shifts in ${ }^{15} \mathrm{~N}$-abundance of Prosopis leaves.

Root biomasses of individual species in mixtures thus may more accurately be estimated if the stable isotope ratios and element concentrations used in calculations for component species are determined on roots that are similar in size to those that comprise the bulk of roots sampled and that are collected concurrently with those that contain the species mixture. Errors made in estimating biomass of the first species in a mixture will be propagated in the sequential calculation of remaining biomasses.

Care also must be taken with this as with most tracer methods to quantify root biomasses to insure that senescent and detrital roots are completely removed from samples. The ratios of $\mathrm{C}$ to $\mathrm{N}$ of roots separated from soils with each threespecies combination were considerably lower $(\bar{x} \pm \mathrm{SE}=33.1 \pm 1.7$ across species mixtures and soil depths, $n=24$ ) than most of those determined on surface roots of the individual species (range 33.7 for $P$. glandulosa to 185.9 for $S$. bicolor). This suggests that samples from each depth increment included senescent or detrital roots, the $\mathrm{C}$ and $\mathrm{N}$ concentrations of which were influenced by decomposition and associated microorganisms (Clark, 1977).

Results demonstrate that, with proper precautions, ratios of stable isotopes of $\mathrm{C}$ and $\mathrm{N}$ may be used in concert to determine, for example, root 
biomass of legumes in pastures with $\mathrm{C}_{3}$ and $\mathrm{C}_{4}$ grasses and to study patterns of root growth during invasion by $\mathrm{C}_{3}$ woody species, including legumes like $P$. glandulosa, into predominantly $\mathrm{C}_{4}$ grasslands (Archer, 1989). Differences in the abundances of stable $\mathrm{N}$ isotopes or in $\mathrm{N}$ concentration alone may be exploited to study mechanisms of root competition between legumes and other $\mathrm{C}_{3}$ species. The method described above can be applied or extended to discern aboveground or belowground biomasses of species in mixtures with stable isotopes of other elements, like hydrogen (Sternberg et al., 1984), or element concentrations that differ consistently among species of interest.

\section{Conclusion}

Differences in stable isotope signatures of species provide a reliable, more rapid, and in some cases, safer method to estimate root biomass of single species or functional groups of plants than more tedious and subjective manual separation of roots or root tracings and potentially more hazardous radioisotope labelling of plants or soils where root exudation, movement of label through soil, and a nonuniform label distribution within plant tissues may limit reliability. Finally, this method may prove a powerful adjunct to water depletion and tracer methods of assessing root activity to determine both structure and function of potentially competing root systems of associated species, and to investigate the role of spatial and temporal separation of root growth and activity in promoting co-existence of plant species.

\section{Acknowledgements}

Anne Gibson extracted roots from soil, processed samples, and prepared figures. Dr F Wes Chichester kindly provided the ground plant material used to enrich soils with ${ }^{15} \mathrm{~N}$. We also thank B B McInteer of Isotope Services, Inc. for careful analyses of $\mathrm{C}$ and $\mathrm{N}$ isotopes in plant materials. Drs F Wes Chichester, Anthony Svejcar, and Charles Tischler provided helpful reviews of the manuscript.

\section{References}

Archer S 1989 Have southern Texas savannas been converted to woodlands in recent history? Am. Nat. 134, 545-561.

Boutton T W, Arshad M A and Tieszen L L 1983 Stable isotope analysis of termite food habits in East African grasslands. Oecologia 59, 1-6.

Caldwell M M. Eissenstat D M, Richards J H and Allen M F 1985 Competition for phosphorus: Differential uptake from dual-isotope-labeled soil interspaces between shrub and grass. Science $229,384-386$.

Caldwell $M$ M, Richards $\mathbf{J} \mathbf{H}$, Manwaring $\mathrm{J} H$ and Eissenstat D M 1987 Rapid shifts in phosphate acquisition show direct competition between neighbouring plants. Nature 327 . 615-616.

Clark F E 1977 Internal cycling of ${ }^{15}$ nitrogen in shortgrass prairic. Ecology 58, 1322-1333.

Davis S D and Mooney H A 1986 Water use patterns of four co-occurring chaparral shrubs. Oecologia 70, 172-177.

Dormaar J F. Smoliak S and Johnston A 1981 Seasonal fluctuations of blue grama roots and chemical characteristics. J. Range Manage. 34, 62-64.

Dzurec R S. Boutton T W, Caldwell M M and Smith B N 1985 Carbon isotope ratios of soil organic matter and their use in assessing community composition changes in Curlew Valley. Utah. Oecologia 66, 17-24.

Fitter A H 1986 Spatial and temporal patterns of root activity in a species-rich alluvial grassland. Oecologia 69, 594-599.

Goldfarb D. Hendrick R and Pregitzer K 1990 Seasonal nitrogen and carbon concentrations in white, brown and woody fine roots of sugar maple (Acer saccharum Marsh). Plant and Soil 126, 144-148.

Huckabee J W Jr. Thompson D R, Wyrick J C and Paulat E G 1977 Soil Survey Bell County Texas. USDA. Soil Conservation Service.

Ludlow M M, Troughton J H and Jones R J 1976 A technique for determining the proportion of $C_{3}$ and $C_{4}$ species in plant samples using stable natural isotopes of carbon. J. Agric. Sci., Camb. 87, 625-632.

McClaugherty C A. Aber J D and Melillo J M 1982 The role of fine roots in the organic matter and nitrogen budgets of two forested ecosystems. Ecology 63, 1481-1490.

McKane RB, Grigal D F and Russell M P 1990 Spatiotemporal differences in ${ }^{15} \mathrm{~N}$ uptake and the organization of an old-field plant community. Ecology 71, 1126-1132.

Meier C E. Grier C C and Cole D W 1985 Below- and aboveground $\mathrm{N}$ and $\mathrm{P}$ use by Abies amabilis stands. Ecology $66,1928-1942$.

Morris G F. Carson R B, Shearer D A and Jopkiewicz W T 1968 Comparison of the automatic Dumas (Coleman Model 29A Nitrogen Analyzer II) and Kjeldahl methods for the determination of total nitrogen in agricultural materials. J. Assoc. Off. Anal. Chem. 51, 216-219.

Pinder J E III and Kroh G C 1987 Insect herbivory and photosynthetic pathways in old-field ecosystems. Ecology 68, 254-259.

Rumbaugh M D, Clark D H and Pendery B M 1988 Determination of root mass ratios in alfalfa-grass mixtures using near infrared reflectance spectroscopy. J. Range Manage. 41. $488-490$. 
Shearer $\mathrm{G}$ and Kohl D H $1986 \mathrm{~N}_{2}$-fixation in field settings: Estimations based on natural ${ }^{15} \mathrm{~N}$ abundance. Aust. $\mathrm{J}$. Plant Physiol. 13, 699-756.

Shearer G, Kohl D H, Virginia R A, Bryan B A, Skeeters J L, Nilsen E T, Sharifi M R and Rundel P W 1983 Estimates of $\mathrm{N}_{2}$-fixation from variation in the natural abundance of ${ }^{15} \mathrm{~N}$ in Sonoran Desert ecosystems. Oecologia 56, 365-373.

Smith B N and Epstein S 1971 Two categories of ${ }^{13} \mathrm{C} /{ }^{12} \mathrm{C}$ ratios for higher plants. Plant Physiol, 47, 380-384.

Sternberg L O, DeNiro M J and Johnson H B 1984 Isotope ratios of cellulose from plants having different photosynthetic pathways. Plant Physiol. 74, 557-561.

Svejcar T J and Boutton T W 1985 The use of stable carbon isotope analysis in rooting studies. Oecologia 67, 205-208.

Svejcar T J, Boutton T W and Christiansen S 1988 Rooting dynamics of Medicago sativa seedlings growing in association with Bothriochloa caucasica. Oecologia 77, 453-456.

Tieszen L L and Boutton T W 1989 Stable carbon isotopes in terrestrial ecosystem research. In Stable Isotopes in Ecological Research. Eds. P W Rundel, J R Ehleringer and K A Nagy. pp 167-195. Ecological Studies Series. Springer-Verlag, New York.

Tieszen L L, Hein D, Ovortrup A A, Troughton $\mathbf{J} \mathrm{H}$ and Imbamba S K 1979 Use of $\delta{ }^{13} \mathrm{C}$ values to determine vegetation selectivity in East African herbivores. Oecologia 37, 351-359.

Tieszen L L and Imbamba S K 1980 Photosynthetic systems, carbon isotope discrimination and herbivore selectivity in Kenya. Afr. J. Ecol. 18, 237-242.

Veresoglou D S and Fitter A H 1984 Spatial and temporal patterns of growth and nutrient uptake of five co-existing grasses. J. Ecol. 72, 259-272.

Virginia R A and Delwiche C C 1982 Natural ${ }^{15} \mathrm{~N}$ abundance of presumed $\mathrm{N}_{2}$-fixing and non- $\mathrm{N}_{2}$-fixing plants from selected ecosystems. Oecologia 54, 317-325.

Virginia R A, Jarrell W M, Rundel P W, Kohl D H and Shearer G 1989 The use of variation in the natural abundance of ${ }^{15} \mathrm{~N}$ to assess symbiotic nitrogen fixation by woody plants. In Stable Isotopes in Ecological Research. Eds. P W Rundel, J R Ehleringer and K A Nagy. pp 375-394. Ecological Studies Series. Springer-Verlag, New York. 